\title{
A fábrica da educação: da especializaçâo taylorista à flexibilizaçáo toyotista, de Ricardo Antunes e Geraldo Augusto Pinto
}

Sáo Paulo: Cortez, 2017. 115 ps. (Coleção Questóes da Nossa Época). v. 58.

\begin{abstract}
Alex Martins de Oliveira Doutorando em Educação pela Universidade do Vale do Rio dos Sinos. Professor do Instituto Federal de Educação, Ciência e Tecnologia do Rio Grande do Sul, Porto Alegre, RS - Brasil alex.oliveira@poa.ifrs.edu.br

Leandro Sieben Doutor em Educação pela Universidade do Vale do Rio dos Sinos. Professor/Diretor Colégio Martinus, Curitiba, PR - Brasil leandrosete@gmail.com

Antonio Ademar Guimarães Mestre em Administração pela Universidade do Vale do Rio dos Sinos. Professor da Faculdade Instituição Evangélica de Novo Hamburgo, Novo Hamburgo, RS - Brasil. antonio@ienh.com.br
\end{abstract}

O livro traz para o debate os desafios contemporâneos das mudanças na forma de organização do trabalho para a educação questionando: Elas influenciaram as demandas de formação dos trabalhadores no século XX? Que concepçôes motivaram essas mudanças e quais interesses representavam? E, diante desse quadro, a educaçáo ainda pode oferecer alguma perspectiva influência na emancipação dos trabalhadores?

$\mathrm{Na}$ elaboraçáo de respostas a esses questionamentos, os autores organizam o livro com uma introdução mais oito capítulos, detalhando os diversos sistemas de gestáo do trabalho e a correspondente educaçấo. Na introdução são refletidas questóes históricas como a escola que vigorou ao longo do chamado 'século do automóvel' e o porquê de esse projeto sofrer fortes modificaçóes, diante do questionamento sobre qual era a formação necessária para os trabalhadores dessa época; e, nos dias de hoje, o que pretendem os formuladores dos novos modelos de produçáo. Concluem os autores que ainda impera o utilitarismo em relação à formação do trabalhador e a imposição da razão instrumental. 
O primeiro capítulo sobre a produção e o trabalho alienado inicia questionando por que o mundo da produção tem importância na história humana: O que é, afinal, o mundo da produção e como se desenha o mundo do trabalho no interior do processo produtivo? Com base nos conceitos de Marx e Hegel, os autores alertam que não podemos realizar nenhuma análise da vida em sociedade de forma fragmentada. Para a compreensão das "ricas conexôes do mundo complexo das causalidades e das açôes humanas" (p. 9) apoiam-se na categoria totalidade de Marx, para analisar os momentos que compóem o econômico, o político, o ideológico e o valorativo, que nos conduzem a processos reciprocamente determinantes e determinados.

O capitulo dois apresenta o sistema taylorista de gestão da produção que foi desenvolvido e propagado no decorrer do século XX, a partir dos estudos de Frederick Winslow Taylor (1856-1915), que originou o livro Princípios da Administração Científica. A obra foi organizada em torno das principais estratégias de Taylor para a implantação da administração científica, cujo objetivo era chegar a um processo produtivo eficiente.

Já no capítulo três, composto pelas açóes do fordismo e a produção industrial, os autores destacam as principais características da linha de montagem e a padronização técnica típica da produção em larga escala, tendo Henry Ford (1863-1947) como precursor da 'indústria de massa'. Trata-se de um modelo de produção que, aliado às teorizaçóes de Taylor, realizou mudanças na organização do trabalho fabril e influenciou o consumo e circulação dos produtos. A empresa Ford foi considerada uma das mais importantes indústrias do capitalismo contemporâneo, sendo o seu fundador também considerado um obstinado pela produtividade do trabalho.

No capítulo quatro é elaborada uma análise crítica que contextualiza e compara o sistema taylorista-fordista e o novo mundo da fábrica. Para os autores, esse sistema possui muitos elementos que já haviam sido apontados por Marx, nos capítulos iniciais de $O$ Capital, sobre a relação da grande indústria do século XIX e a valorização do trabalho fragmentado no século $\mathrm{XX}$, recebendo destaque a própria produção em série.

O capítulo cinco aborda a exaustão dos processos de produçáa baseados na perspectiva do taylorismo-fordismo. Esse esgotamento exigiu do capital hegemônico uma mudança de paradigma no modo de acúmulo de 
riquezas. Dessa forma, com base em algumas experiências mundiais, sobretudo a partir dos anos 1980, o modelo produtivo desenvolvido pela empresa japonesa Toyota Motor Company, que ficou conhecido como toyotismo, combinou elementos de continuidade e descontinuidade do modelo anterior e se transformou no padrão a ser seguido e copiado mundo afora. Dentre suas características, destacam-se: a) produção ligada à demanda em vez da produçáo em massa; b) metodologia baseada no just in time, pela qual se busca continuamente a redução dos estoques; c) estrutura produtiva horizontalizada, fundindo-se à rede empresas terceiras nas quais o trabalho em equipe é um dos pontos principais e cada trabalhador/a opera mais de uma máquina dentro do processo (Nen-Ko).

No capítulo seis, os autores propóem um diálogo acerca da educação de gestores e trabalhadores frente aos desafios da produção industrial do século XX. O modelo inspirado em Ford e teorizado por Taylor desprezava o conhecimento dos/as trabalhadores/as, transformando suas atividades em 'tarefas'. O objetivo era atacar os saberes-fazeres e o poder de barganha dos/as trabalhadores/as, limitando seus conhecimentos a especializações fragmentadas. Essa educação tinha como principal função a formação de força de trabalho para o mercado. De uma forma geral, nesse modelo de educação o estudante deveria ser preparado para as tarefas rotinizantes das linhas de produção segmentadas e superficiais. Além disso, o/a trabalhador/a deveria ter um bom grau de disciplina e um alto senso de obediência para suportar e viver atendendo demandas de sua linha de produção sem questionamentos. O modelo taylorista-fordista chamado Trainning Within Industry (TWI) - treinamento dentro da indústria -, foi propagado por todo o mundo, principalmente a partir do esforço de guerra nos Estado Unidos.

O capítulo sete mostra que o sistema taylorista-fordista iniciou no mundo uma nova metodologia de educação industrial, na qual vigoraria a perspectiva do treinamento de caráter estritamente utilitário, o que seria suficiente para que o/a trabalhador/a pudesse atender às demandas da produção como um todo. Pela expansão mundial do TWI, essa metodologia foi aperfeiçoada no Japáo, com inserção de mecanismos inovadores como o kaizen, no qual se aplicava o princípio de melhoria contínua. Uma vez que a indústria japonesa ainda estava em processo de recuperação nas décadas de 50-60 e que o aumento de produtividade era um pressuposto 
essencial naquele momento histórico, não só o aumento da produtividade se tornava obrigatória, mas também a flexibilidade na produção - essa a razão do êxito do TTWI desenvolvido na fábrica de motores da Toyota. Essa mudança de paradigma redesenhou a estrutura de educação. Os novos desafios dos/as trabalhadores/as agora tinham que ser enfrentados pelo sistema educacional: com a expansão do toyotismo, o capital reinventou a relação empresa/trabalhador/a e propôs a flexibilização da produção mundial agora se aplicam às relaçóes trabalhador/empresa. $\mathrm{O}$ trabalho passou a ser um produto do 'empresário' trabalhador, sob o nome de capital humano, pelo qual polivalência, multifuncionalidade e flexibilidade se tornaram elementos essenciais na educação dos trabalhadores.

O capitulo oito conclui o livro com uma reflexão sobre a educação humanista, omnilateral e emancipadora que embasa a crítica ao modelo educacional unilateral, instrumental e alienado que, no capitalismo, reflete a separação entre homem de trabalho intelectual (homo sapiens) e manual (homo faber). Os modelos de produção taylorista-fordista e toyotista de produção capitalista se tornaram, ao longo desse período, as estruturas fundamentais de influência nos modelos de educação pelo mundo, transformando o trabalho de homens e mulheres em simples mercadorias. Com essa influência, a educação tem se convertido numa ferramenta a serviço do capital, em prejuízo de toda uma sociedade de trabalhadores.

O livro de Antunes e Augusto Pinto retoma uma temática que se mantém atualíssima ao escancarar um histórico de submissão da educação à lógica do capital que expóe as feridas atuais; ao mesmo tempo, contribui para a busca de respostas aos desafios das metamorfoses do trabalho. Recomendamos a leitura! 